\title{
Comparing Finnish and Russian Work Life
}

\author{
T. SAARI*, M. SIPPOLA**, H. MELIN***, A. EFENDIEV****,E. BALABANOVA*****
}

\begin{abstract}
*Tiina Saari-Post Doctoral Researcher, University of Tampere, Finland. Address: 4 Kalevantie, 33100, Tampere, Finland.E-mail: tiina.p.saari@uta.fi

**Markku Sippola - University Lecturer, University of Tampere, Finland. Address: 4 Kalevantie,33100, Tampere, Finland.E-mail: Markku.Sippola@uta.fi

***Harry Melin - Professor, Vice Rector, University of Tampere, Finland. Address: 4 Kalevantie, 33100, Tampere, Finland. E-mail: harri.melin@uta.fi

****Azer Efendiev - DSc in Philosophy, Professor, National Research University Higher School of Economics. Address: 20 Myasnitskaya St., Moscow, 101000, Russian Federation. E-mail: efendiev@hse.ru

*****Evgeniya Balabanova - DSc in Sociology, Professor, National Research University Higher School of Economics. Address: 20 Myasnitskaya St., Moscow, 101000, Russian Federation.E-mail: balabanova@hse.ru
\end{abstract}

Citation: Saari T., Sippola M., Melin H., Efendiev A., Balabanova E. (2018) Comparing Finnish and Russian Work Life. Mir Rossii, vol. 27, no 2, pp. 90-108. DOI: 10.17323/1811-038X-2018-27-2-90-108

This article compares the differences and similarities between Finnish and Russian work life, with special focus on how employees perceive the importance of employment and pay, favouritism in the workplace, and satisfaction with leadership. The contrasts between the two countries make for an interesting comparison: Finland is one of the world leaders in quality of work life, while many workplace practices in Russia date from the Soviet era. Our analysis shows that, as expected, pay is much more important than job content to Russian employees, while job content is more important than pay to Finnish employees. Work and employment is highly valued in both countries, but more so in Russia. Russia is often described as backward in its management and leadership styles, yet we found that Russian employees are more satisfied with some aspects of leadership in the workplace than Finnish employees.

Key words: work life, work payment, quality of work life, workplace discrimination, leadership styles

\section{Introduction}

This article compares Finnish and Russian work life. The main focus is on aspects of work life that, based on the literature, can be expected to differ between the two countries: the perceived importance of employment and pay for employees, favouritism, and employee satisfaction with leadership. Our aim is to identify which indicators show differences

\footnotetext{
1 This research was funded by the Finnish Work Environment Fund (project no. 115198) and by the National Research University Higher School of Economics through the Basic Research Programme.
} 
and which show similarities between the two countries. The data for our research come from quality of life surveys conducted in 2013 (Finland) and 2014 (Russia), which allow for direct comparisons. European Working Conditions Surveys $(E W C S)$ provide another useful source of information on country differences, but Russia does not take part in these surveys. The current study is unique in that the comparison includes the Russian workplace, which is based on very different foundations than its northern and western European counterparts. There are only very few earlier comparisons of Finnish and Russian work life (but see [Blom 1991; Saari, Melin, Balabanova, Efendiev 2017]).

Finland and Russia have extensive trade relations. Hundreds of Finnish companies are active in Russia, and in recent years Russian companies have stepped up their investment in Finland. There are also growing numbers of Russian immigrants in the Finnish labour market today. For these reasons alone it is important to research and understand the differences and similarities between the work cultures of these two countries.

Russia and Russian research are often surrounded by myths and beliefs that sometimes date back hundreds of years. Tolvanen [Tolvanen 2012] says that one such myth stems from the lines originally penned by poet Fyodor Ivanovich Tyutchev: "Russia cannot be understood with the mind alone, / No ordinary yardstick can span her greatness: / She stands alone, unique - / In Russia, one can only believe." In this article we are determined to look beyond and unravel some of these myths and beliefs.

Earlier research has shown that Finnish and Russian work life differ from each other in many areas. Finnish work life may be described as representative of the Nordic type; and Russian work life as representative of the post-socialist type. Together with its Nordic neighbours, Finland is a European and indeed world leader in work life quality (e.g. [Hartikainen, Anttila, Oinas, Nätti 2010; Parent-Thirion, Fernández Macias, Hurley, Vermeylen 2007]). Russia, on the other hand, still retains many workplace practices dating from the Soviet era -25 years after the collapse of socialism [Tomanovic, Ignjatovic 2006; Puffer, McCarthy 2011].

There are also strong notions about Russian work life that are based on the idea of historical path dependence. Work in Russia is often described as entrenched in customs and traditions dating back to the Soviet era [Puffer, McCarthy 2011]. One such notion is the belief that Russian work life today is still characterized by blat culture, a reliance on personal favours and informal networks in the workplace [Liuhto 1999, p. 19]. Especially in the Soviet era, Russian business management was highly paternalistic and authoritarian in style [Clarke 2004; Melin 2005], and even today it is suggested that Russian employees long for strong and charismatic leaders [Fey, Shekshnia 2011]. On the other hand, there has been a growing drive in recent years to modernize management styles in Russia [Balabanova, Efendiev, Ehrnrooth, Koveshnikov 2015]. The Russian labour market is rigid inasmuch as employees are not easily dismissed, and under normal cyclical conditions there is only little flexibility in wages and working hours. On the other hand, the labour market is highly flexible in the sense that during periods of economic crisis, employees are prepared to exercise flexibility in wages and working hours [Gurkov, Zelenova, Saidov 2012; Kapelyushnikov, Kuznetsov, Kuznetsova 2011]. It is reasonable to assume then that Russian employees attach great importance to work and job security, so much so that they are prepared to make pay and working hour concessions to keep their jobs.

The article is structured as follows: We begin by providing an overview of the Russian labour market and comparing it with the Finnish labour market. There are separate sections on the meaning and importance of employment and pay, favouritism, and 
leadership. We then proceed to describe our research data and methods. The analyses are followed by a summary and conclusions, which discuss the relevance of the results in a wider context.

\section{Russia and Finland: two different work life paths}

Soviet work life has been extensively researched from numerous different perspectives by both Russian and other scholars. The labour process debate in particular has produced some interesting theorizations about socialist and capitalist workplaces and the transformation from socialist to capitalist work life. Based on fieldwork in Russian factories, these changes have been described among others in by Burawoy [Burawoy 1981], Burawoy and Krotov [Burawoy, Krotov 1993] and Clarke [Clarke 1993]. More recently, Russian work life has been discussed above all in the business management literature (e.g. [Fey, Björkman 2007; Hollinshead 2007; Yakubovich, Kozina 2007; Gurkov, Zelenova 2009]).

In recent decades Russian work life and the Russian labour market have been characterized simultaneously by change and stability. There have been some changes since the collapse of the Soviet Union, but critics maintain that progress has been slow and that many customs dating from the Soviet era still persist [Puffer, McCarthy 2011]. In the 1990s Russia saw rising income inequality, and manager earnings increased sharply. There was growing unemployment, and at the same time the pace of work intensified. Employees suffered a decline in autonomy, while supervisors and managers gained increasing power and control [Melin 2002, p. 73]. Today, Russian organizations remain hierarchic and authoritarian in their management styles, and employees have limited autonomy: all the strings are pulled by managers [Popova 2010; Puffer, McCarthy 2011; Gimpelson, Kapeliushnikov 2011; Fey, Shekshnia 2011]. The Russian labour market is dominated by large organizations, and state enterprises continue to have a major role. Historically, company managers have wielded strong power resources in Russia, more so than their counterparts in the west [Clarke 2006; Blom, Melin, Sarno, Sarno 2007]. The quality of work life development has been sluggish in Russia, although some recent studies indicate that investment in management and management training has been stepped up with a view to modernizing management styles [Sarno 2012, p. 58; Balabanova, Efendiev, Ehrnrooth, Koveshnikov 2015].

The development of Finnish work life has been more of a success story. Finland compares favourably with the other Nordic countries and indeed the whole of Europe in terms of the quality of its work life [Hartikainen, Anttila, Oinas, Nätti 2010; Parent-Thirion, Fernández Macias, Hurley, Vermeylen 2007]. Quality of work life is grounded in a physical and psychosocial working environment which presents no health and safety threat to employees. The concept of the quality of work life comprises such elements as professional skills and autonomy, work-related pressure, the input and exertion required by work, increasing work intensity, wages, job risks and uncertainties and subjective experiences of well-being [Green 2006]. When measured on these indicators, employees in Finland report a relatively high degree of satisfaction. The high quality of work in Finland is reflected above all in opportunities for personal growth and development in the workplace as well as in high levels of job autonomy [Hartikainen, Anttila, 
Oinas, Nätti 2010; Parent-Thirion, Fernández Macías, Hurley, Vermeylen 2007]. It used to be common to describe Finland as a remote country on the European periphery, but it is now increasingly portrayed as a progressive information society that in country brand comparisons, for instance, ranks alongside the other Nordic countries [Alasoini, Antila, Hakonen, Hasu, Lyly-Yrjänäinen, Niemi, Pakarinen, Ramstad, Stålhammar 2016].

Finland and Finnish work life have evolved in a very short space of time from an agrarian into a service society. Today, Finland is best described as an information society [Castells, Himanen 2002, p. 150; Moen, Lilja 2005, p. 357]. Work life in Finland and in Russia differ not only in terms of quality, but also in work culture. Ylöstalo [Ylöstalo 2007] compared the work cultures of 74 countries and found that Finland clearly fits the profile of northern European countries, although it does have some distinctive national characteristics. The comparison shows that in Finland, employees are separated by only a very short distance to power and authorities. This implies a low degree of inequality. Finnish work culture is individualistic and highly feminine. Individualism refers to the high degree of independent decision-making and high personal satisfaction from a job well done. According to Ylöstalo, the key characteristics of an ideal job in feminine societies include good relations with superiors, mutual cooperation and job security. In masculine societies, the priority is instead on high income, recognition for a job well done, good prospects for advancement, and a challenging job. Research has shown that Russian culture is characterized by large power distances, although various indicators suggest that these distances have been significantly reduced in the post-socialist era [Balykina 2015]. Countries with large power distances are characterized by an uneven distribution of power, which in principle is accepted even by those who are not in positions of power [Javidan, Dorfman, de Luque, House 2006].

Before we move on to describe our data and methods, the following sections provide an overview of the work life indicators used in our country comparisons, i.e. the meaning and importance of employment and pay for employees, favouritism and discrimination, and various dimensions of leadership.

\section{Importance of employment and pay}

Materialist values are highly prominent in Russia, and people's motivation to work may therefore be instrumental. The biggest motivation to work comes from the pay, not the content of the job [Magun, Rudnev 2012]. Another potential source for the instrumental meaning of work is the absence of flexibility in wages and working hours and the rigidities of dismissal procedures [Kapelyushnikov, Kuznetsov, Kuznetsova 2011]. Given the scarcity of formal social and unemployment security systems, wages are typically the most important source of social security in Russia. Indeed, people in post-socialist countries attach greater importance to wage employment than in the Nordic countries, where people value holidays, leisure and human relations more than work [Perceptions of Living Conditions 2004, p. 42].

The same difference in the appreciation of employment is seen among managers as well. Fey [Fey 2005] discovered that Russian managers are motivated by pay, whereas the chief motivation for Swedish managers was a pleasant work environment. Furthermore, it has been shown that power and material values are very prominent in Russia, both in and outside the world of work, while less importance is given to such factors as equality and justice [Fey 2005; Magun, Rudnev 2012, p. 41]. 


\section{Favouritism and discrimination}

The concept of organizational justice refers to the perceived fairness of work organization practices, as seen from the employee's point of view (see [Gilliland 1993]). Experiences of fairness and justice correlate with job satisfaction [Swerdlow, Roehl 2003, p. 363]. Organizational justice therefore also includes discrimination based on favouritism, or rather the prevention of discrimination.

It is reasonable to assume that workplace discrimination due to favouritism is less common in Finland than Russia, where recruitment, for instance, is largely based on informal contact networks [Gurkov, Zelenova 2009]. Although blat culture or the economy of favours has been on the decline in recent years [Ledeneva 2008], informal blat networks were still important in the 1990s. Alasheev and colleagues [Alasheev, Tartakovksaya, Lapshova 1997] found in their case study that personal networks were important to women's opportunities for advancement. Informal business practices have become less common since the economic rebound in the 2000s [Borodkin 2010, p. 252]. It is possible that the rise of individualism associated with Russia's "late modernization" [Walker 2011, p. 4] has contributed to the declining role of social networks in the workplace. On the other hand, Tomasovic and Ignjatovic [Tomasovic, Ignjatovic 2006] point out that these changes have not been very radical.

In Finland, there has been hardly any change in the occurrence of favouritism-based discrimination in the past two decades. According to Statistics Finland's Quality of Work Life Surveys in 1997, 2003, 2008 and 2013, around one-fifth (20-21\%) of employees in all sectors reported such discrimination; among women the figures were $23-25 \%$ and among men 16-18\% [Lehto, Sutela 2008; Sutela, Lehto 2014]. Less than one in ten employees $(8 \%)$ reported personal experiences of discrimination based on favouritism, women (11\%) more often than men (6\%). Since 1997, the figure for men has decreased by one percentage point and for women it has increased by three percentage points [Sutela, Lehto 2014, p. 120].

\section{Leadership}

As discussed earlier, the Finnish workplace can be studied as part of the Nordic work life regime. Finnish management and leadership styles also show strong similarities with the Scandinavian model of business management. Nordic managers are more employee oriented and more tolerant of conflicts in the workplace than their southern European colleagues [Lindell, Arvonen 1996, p. 80]. This may well have to do with the Nordic tradition of industrial relations, where conflicts are a natural and now institutionalized feature of the workplace. Analyses of strike action in the Nordic countries confirm that conflicts of interest have certainly not disappeared (see [Stokke, Thörnqvist 2001, pp. 253-254]). Nordic employers allow for reciprocal dialogue with trade unions so long as the latter do not threaten the autonomy of business management [Rogaczewska, Larsen, Nordhaug, Døving, Gjelsvik 2004, p. 248]. Brewster and Larsen [Brewster, Larsen 2000, p. 31] say that Nordic companies have successfully integrated collective bargaining in their human resource management strategies, which has contributed to the reduction in confrontations with trade unions. 
The roots of present-day Russian management and leadership can be traced back to the Soviet era. Soviet corporate culture included the use of personal contact networks in informal activities (blat) and informal procurement networks (tolkachi) [Liuhto 1999, p. 15]. The latter, however, had more to do with management contacts and networks in broader society, rather than with the relationship between management and labour. The inner circle of business management that aimed to conceal and keep informal business activities under wraps (krugovaya poruka) remained largely an internal loyalty system [Liuhto 1999, p. 19]. The blat system, by contrast, had a greater impact and influence on employees, as discussed earlier.

In the 1990s it seemed apparent that business management practices inherited from the Soviet era were continuing to have a major influence on post-socialist leadership practices. It looked like some features of "management sovieticus" such as irrationality, the overemphasis on production volumes, informal workplace practices and an all-pervasive bureaucracy, were just refusing to die [Liuhto 1999, p. 23-25]. Likewise, employees of privatized, formerly state-owned enterprises seem to have it in their mind that these companies still had the exact same functions and social responsibilities in the post-socialist era, which was connected with a paternalistic and authoritarian management style [Clarke 2004; Liuhto 1999, p. 39; Nikula 1997, p. 131]. Authoritarian paternalism has been a natural strategy to which both business management and employees could resort in the climate of uncertainty that followed with the collapse of the Soviet Union.

\section{Research question, data and methods}

The aim of our study is to establish the veracity of some of the convictions held about Russian work life. Specifically, our research question is this: To what extent do Finland and Russia differ in the perceived importance of employment and pay, favouritism and related discrimination, and the perceived quality of management and leadership? We work from the assumption that employment is valued more highly in Russia than in Finland, and that Russian employees experience more favouritism-based discrimination and are less satisfied with leadership in the workplace.

Our data come from Finnish and Russian quality of work life surveys. Data on Finnish employees have been compiled regularly by Statistics Finland at roughly five-year intervals since 1977. Data collection is via telephone and face-to-face interviews. For the present analysis we use the most recent dataset available (2013). The Finnish dataset is a random sample covering the whole of Finland, and it provides a representative picture of the Finnish wage-earning population. The Russian data were collected by the Moscow-based Higher School of Economics with the assistance of a company specializing in questionnaire research. Making use where possible of the Finnish quality of work life instrument, the Russian data were collected in 2014 in three cities: Moscow, Omsk and Nizhni Novgorod, as the collection a nationally representative sample would have been practically infeasible and overly expensive. The three cities were intended to represent different types of Russian urban areas: one large metropolitan capital area, one city representing the more "European" part of Russia (Nizhni Novgorod), and one major Siberian city. 
In both datasets the respondents are aged 16-65 and they represent all branches of industry. In Russia, data collection was restricted to full-time private sector employees with an employment contract of indefinite duration. For the purposes of our comparisons we drew a corresponding sample from the Finnish data. The final, combined dataset includes 2,641 Finnish and 780 Russian respondents.

There are some data-related restrictions that limit the generalizability of our findings. Firstly, the dataset includes respondents who have supervisory or management duties and who may have a more positive overall perception of work life than those strictly in employee positions. Furthermore, as data collection in Russia was confined to three cities, the results are not generalizable to the national level in the same way as in the Finnish case. Also, since the results concern continuous full-time employees only, they can shed no light on the situation of people in atypical employment, that is, those in part-time and fixed-term jobs. In Finland, employees on fixed-term contracts account for around $8 \%$ of all private sector employees [Sutela, Lehto 2014]; in Russia the corresponding figure is around 6\% [Smirnykh, Wörgötter 2013]. It has been suggested that in the Russian private sector in particular, there is a tendency to favour informal and atypical employment at the expense of formal and permanent contracts, but research has shown that by the late 1990s most private sector employees were under contracts of indefinite duration [Clarke, Borisov 1999]. Even in the Russian data, then, only a small number of private sector employees are excluded from our analysis because the sample comprises employees with contracts of indefinite duration.

Most of the questions reported below are presented in their full, original form. The items concerning management and leadership, however, have been abridged for inclusion in the figures as follows: My supervisor trusts his/her employees (trust), My supervisor gives praise for a job well done (positive feedback), My supervisor is inspiring (encouragement), My supervisor speaks openly about all workplace matters (openness), My supervisor provides sufficient feedback on how I have performed in my job (feedback), My supervisor knows how to settle conflicts between employees (mediation skills). All leadership items were presented in the form of statements with a five-point Likert response scale ( 1 fully agree ... 5 fully disagree). The responses were not rescaled as we were mainly interested in identifying those employees who were very satisfied with leadership in the workplace, i.e. who said they fully agreed with the statement; and on the other hand those who were very dissatisfied, or who said they fully disagreed with the statement. A reduced response scale would only have obscured from view the clear differences we can now see in employee satisfaction. We have chosen to use cross tabulation as our descriptive method of analysis. Significance levels are determined using Pearson's chi-squared test.

\section{Results}

Employment and pay mean more to Russians

Work and employment is an important part of life. Work takes up a large part of our day, and we depend on work for our livelihood. Our analysis suggests that work is more 
important to Russians than it is to Finnish employees: $93 \%$ of Russian employees describe work as extremely important to them, compared to $62 \%$ of Finnish employees (Figure 1). Finnish employees attach somewhat more importance to leisure than Russians: $43 \%$ in Finland and $35 \%$ in Russia describe leisure as very important. There are no country differences in the value given to family: $89 \%$ of Finns and $90 \%$ of Russians say that family is an extremely important part of life.

The importance of pay to Russian employees is clearly demonstrated by the results for the importance they attach to wages as compared to job content (Figure 2). Finnish and Russian employees have opposite views on the importance of pay and job content. For more than half of Russians pay is more important than job content, while just under half of Finnish employees say that job content is rather somewhat more important than pay. Only $13 \%$ of Finnish employees take the view that pay is most important. However, even among Finnish employees less than one-tenth (9\%) think that job content is the single most important motive for work, among Russian employees $2 \%$ agree with this statement.

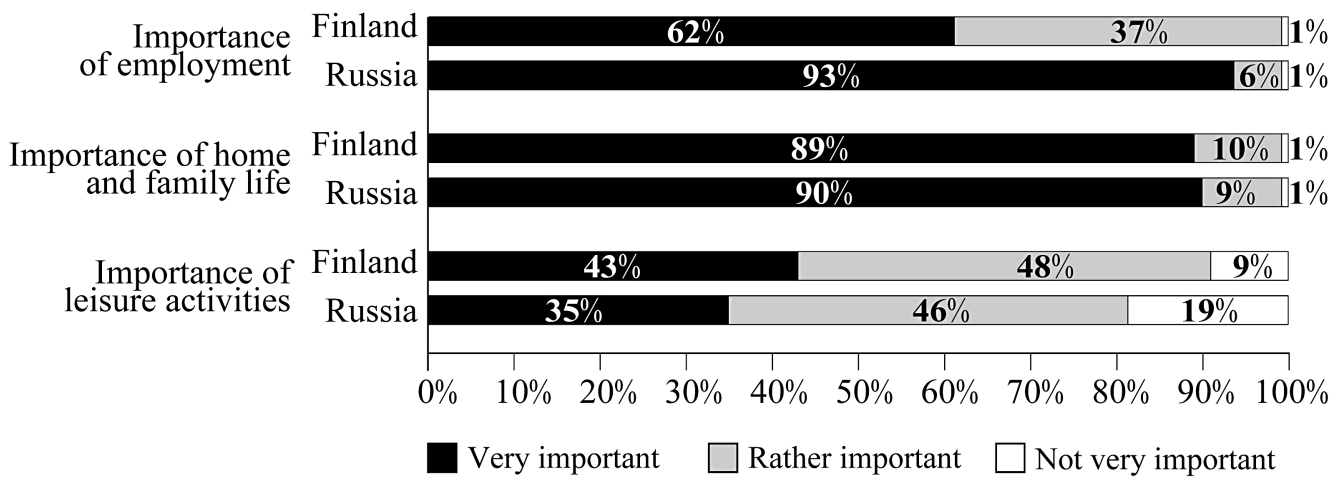

Figure 1. Importance of employment, home and family life and leisure activities

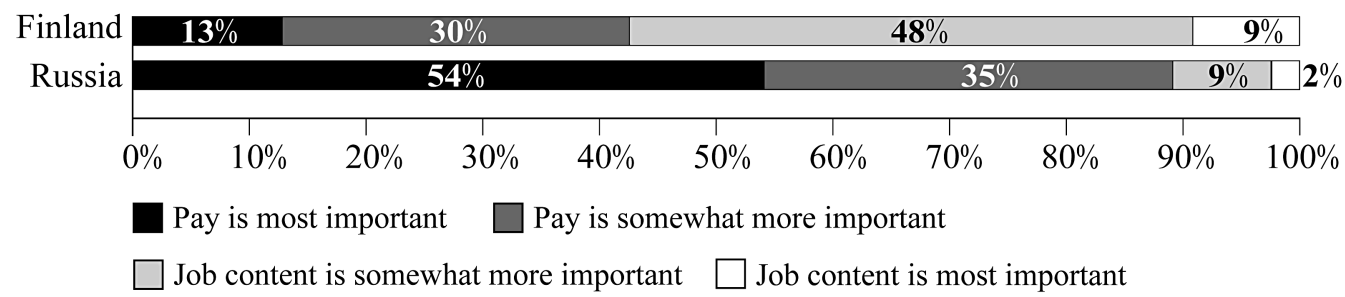

Figure 2. Importance of pay and job content 


\section{Favouritism and related discrimination somewhat more common in Finland}

There are only minor country differences in the experience of favouritism and related discrimination. In both countries the majority of employees report no favouritism in their workplace. $20 \%$ of Finnish employees say that favouritism does occur in their workplace, but only $7 \%$ say they have personally experienced discrimination because of favouritism. The corresponding figures in Russia are $13 \%$ and $4 \%$. In the light of these results it seems that favouritism is less common in Russia than in Finland, and that a larger proportion of Finnish employees feel they have been discriminated against because of favouritism (Figure 3).

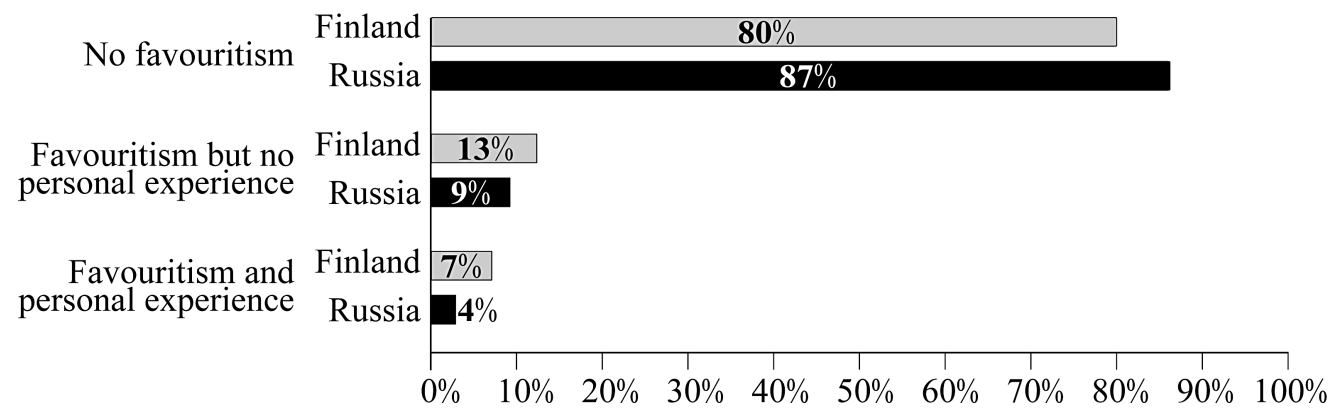

Figure 3. Favouritism and related discrimination

Finnish employees more satisfied with leadership in workplace

When employees in Finland and Russia are asked in general terms how satisfied they are with their closest superior, the results are roughly the same: almost one-third in both countries (Finland 28\%, Russia 29\%) say they are very satisfied. The proportion indicating they are rather satisfied is just under half in Finland (47\%) and just over half in Russia (56\%). In other words, the Russian responses lean slightly more towards a sense of satisfaction.

Upon closer examination, however, we find that Russian employees are not quite as satisfied with leadership in the workplace after all. Figure 4 compares Finnish and Russian employee satisfaction with their superiors' encouragement and inspiration, positive feedback, and trust shown in employees. In each item the proportion of respondents indicating they are very satisfied is higher in Finland. 21\% of Finnish employees are very satisfied with how their superior inspires subordinates, compared $14 \%$ of Russian employees. $29 \%$ of Finnish employees are very satisfied with the way their superior provides positive feedback, compared with $13 \%$ in Russia. The country difference is even more striking in the case of their superior's trust: $44 \%$ of Finnish employees are very satisfied with the trust shown in them by their manager, among Russians the proportion is $23 \%$. All the results above are statistically significant $(\mathrm{P}=0.000)$. 


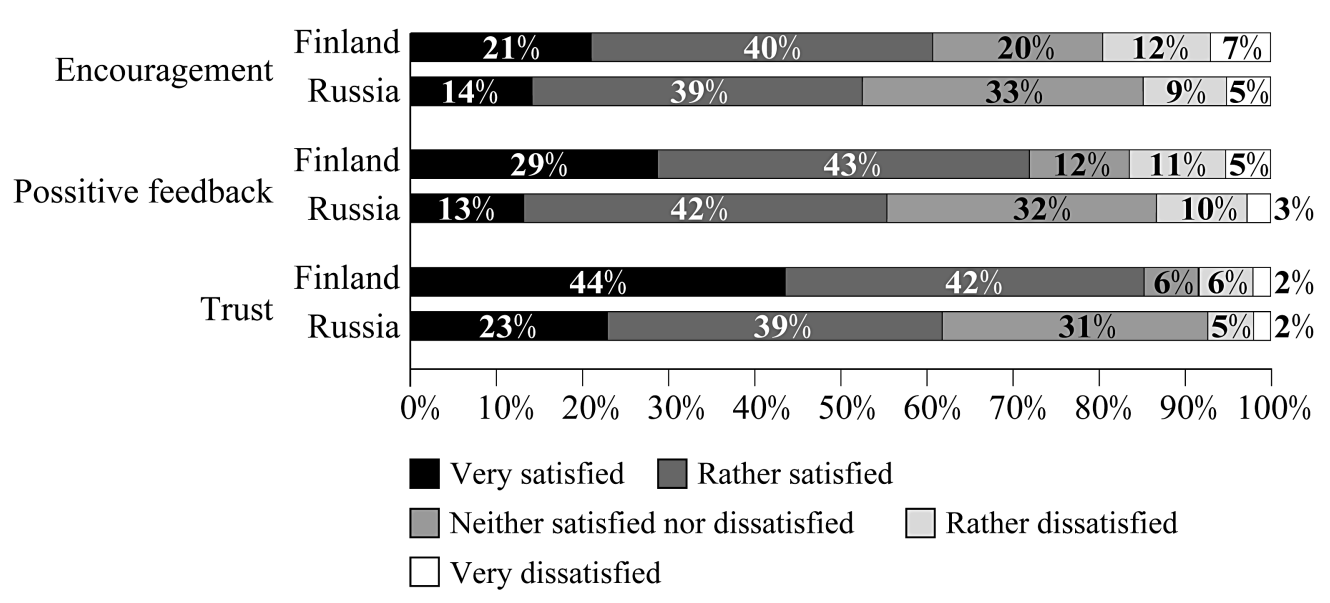

Figure 4. Satisfaction with leadership in the workplace 1

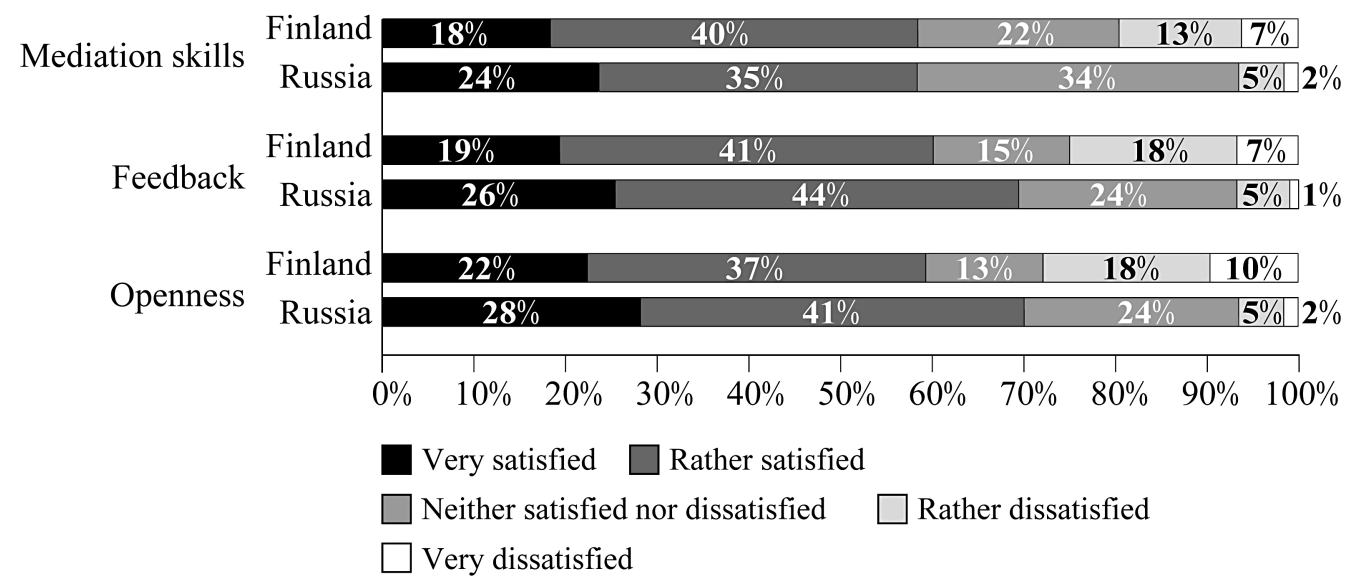

Figure 5. Satisfaction with leadership in the workplace 2

Although a larger proportion of Finnish employees say they are very satisfied, very many Russians indicate that they are "rather satisfied" on all these indicators. In other words, Russian employees are by no means unhappy with the leadership in their workplace. Furthermore, if we look at extreme dissatisfaction, we find that the proportion who are deeply dissatisfied is equally low in Finland and Russia.

Not all leadership items show weaker results for Russia than for Finland. Russian employees are more satisfied than Finnish employees in three areas of leadership in the workplace (Figure 5).

According to our results $24 \%$ of Russian employees are very satisfied with how their superior resolves conflicts in the workplace. In Finland the corresponding share is 18\%. However, if we include both the very satisfied and rather satisfied respondents, the total 
in both countries is around one-half of all respondents. Figure 5 compares the results for praise and positive feedback provided by managers, and showed that Finnish employees are more satisfied than Russian. The results for the provision of feedback in general, then, are the other way round: $26 \%$ of Russians but $19 \%$ of Finnish employees say they are very satisfied. Could it be that it is harder for Finnish managers to offer critical feedback? Russian employees are also more satisfied with their superiors' openness in discussing workplace matters. $28 \%$ of Russian employees and $22 \%$ of Finnish employees are very satisfied with their superior's openness. All the results reported above are statistically significant $(\mathrm{P}=0.000)$. However, the country differences shown in Figure 5 are less pronounced that those in Figure 4.

\section{Finnish and Russian work life: differences and similarities}

In this article we set out to test the veracity of some widely-held notions about Russian work life and on this basis to compare Russian and Finnish work cultures. Our findings suggest that some of these notions are true, others only partly true. As expected, pay is far more important to Russian employees than job content, while the exact opposite is true in Finland. The appreciation of employment is also at a higher level in Russia, although the results indicate that work is highly valued in Finland, too. Contrary to our assumptions, Finnish employees are not more satisfied with every aspect of leadership in the workplace; in some areas Russian employees express greater satisfaction. Another rather surprising discovery was that perceived favouritism was more common in Finland than Russia.

Russian employees consider employment a somewhat more important area of life than Finnish employees, even though is work valued very highly in Finland. In Russia, position and income depend more closely on wages from gainful employment than they do in Finland, where people with no regular income can fall back on social security, at least for the time being. This difference might also be explained by the prominence of materialist values in Russia [Magun, Rudnev 2012; Fey 2005].

Our analysis did not support common notions about favouritism and related discrimination. Finnish employees reported favouritism and experiences of related discrimination more often than Russian employees. It is possible that the dwindling role of informal practices in the workplace in the 2000 s, as observed by Borodkin [Borodkin 2010, p. 252], has also contributed to the decline of favouritism. On the other hand, Gurkov and Zelenova [Gurkov, Zelenova 2009] observed that up to three-quarters of all jobs are still filled through informal recruitment. They saw no major difference in this regard between state enterprises and privately owned companies.

Our results on the scarcity of favouritism and related discrimination in Russia are sharply different from our expectations. Could it be that it is difficult for people to recognize well-established practices as discriminatory or otherwise problematic? It might well be that discrimination in the workplace is not seen as a major problem because Russians consider it "normal" that public officials, for instance, take a discriminatory attitude towards citizens [Rose 2008]. It is also possible that the job market in Russia has become "normalized" and reached roughly the same level as in Finland as a result 
of the growth of individualism [Walker 2011, p. 4], the decline of informal business practices following the economic rebound [Borodkin 2010, p. 252], or the decreasing use of informal contact networks in post-socialist Russia [Ledeneva 2008].

The view that management styles in Russia are outdated and obsolete, by contrast, turned out to be partly true: Finnish employees were more satisfied than Russians in the trust that superiors showed in their subordinates and in how they provided positive feedback, whereas Russians were more satisfied in their superior's openness and ability to provide feedback in general and to settle conflicts in the workplace.

Our results do not lend support to the view that the prevailing management style in Russia is based on rigorous discipline (cf. [Fey, Shekshnia 2012]). However, it is interesting to consider how Russian and Finnish employees understand the meaning of openness and open discussions about workplace issues. Could it be that any information about the organization in Russia is interpreted as an indication of openness, whereas in Finland it is expected by default that there is complete transparency about the organization and that employees are always involved in decision-making? Work cultures certainly matter, and these cultures differ significantly between Finland and Russia. Finnish work culture is characterized by an atmosphere of dialogue and relative openness. Any problems occurring in the workplace are raised as a matter of course and openly discussed. Not so in Russia. In Russia, managers wield more power and they address any problems in the workplace without consulting employees. Employees will discuss these problems among themselves, or at least with their most trusted colleagues. This study did not explore how employee satisfaction with leadership has changed over time. Indeed it is quite possible that Russian leadership styles have changed for the better. Furthermore, our Russian sample only comprises full-time private sector employees in three cities, which must be borne in mind when interpreting the results.

It is important to remember that our data were drawn exclusively from the private sector. In Russia, state-owned enterprises and the public sector continue to have a very prominent role in the labour market. Private companies are still relatively young, and their workforces are younger and better educated than Russian employees on average. Therefore the Russian dataset analysed here does not tell the whole truth about the Russian labour market. Rather, it sheds light on the situation in the most advanced jobs. International comparisons are always challenging, and therefore great caution must be exercised in generalizing the results. It is also necessary to consider whether Finnish and Russian employees will have had different ways of responding to questionnaires and whether this will have affected the results. It has earlier been reported that Russians are less accustomed to completing questionnaires than Finns. In our case we found that the number of missing responses was very high in the Russian dataset. Furthermore, Russian employees' idea of what amounts to "good" or "normal" may well differ from the understandings of Finnish employees (see [Palosuo 2000]).

Our results indicate that Russian work life does not differ significantly from what is considered the normal European way of organizing wage labour. Russian business practices, workplace relations and employee attitudes to work are closely aligned with Finnish views. However, our findings do highlight some differences between Russian and Finnish work life. Despite these differences it would seem there are also some similarities between the two countries. Further comparative research is needed to explore in more detail the causes and consequences of these differences and similarities. 


\section{References}

Alasheev S.Yu., Tartakovksaya I.N., Lapshova E.M. (1997) Podshipnikovyj zavod «Kol’tso»: konservatizm formal'nykh i neformal'nykh struktur [Ball Bearing Factory “The Circle: Conservatism of Formal and Informal Structures]. Predpriyatiya i rynok: dinamika upravleniya $i$ trudovykh otnoshenij $v$ perekhodnyj period (opyt monograficheskikh issledovanij 1989-1995 gg.) [Enterprises and the Market: Dynamics of Management and Work Relations in the Transition Period (Summation of Monographic Studies in 1989-1995] (ed. Kabalina V.I.), Moscow: ROSSPEN, pp. 114-144.

Alasoini T., Antila J., Hakonen N., Hasu M., Lyly-Yrjänäinen M., Niemi M., Pakarinen T., Ramstad E., Stålhammar H. (2016) Hyvä työelämä Suomen kilpailukykytekijänä: työelämäbrändityöryhmän raportti. Työja elinkeinoministeriön julkaisuja 42/2016 [Good Working Life in the Competitive Economy. The Report of the Ministry of Economy 42/2016], Helsinki: Työja elinkeinoministeriö.

Balabanova E., Efendiev A., Ehrnrooth M., Koveshnikov A. (2015) Idiosyncrasy, Heterogeneity and Evolution of Managerial Styles in Contemporary Russia. Baltic Journal of Management, vol. 10, no 1, pp. 2-29.

Balykina G. (2015) Power Distance and Modern Russian Business. Presentation at "Kitekintések 25 éves a győri közgazdászképzés”, Kautz Gyula Emlékkonferencia, on 11 June 2015. Available at: http://kgk.sze.hu/images/dokumentumok/kautzkiadvany2015/Balykina.pdf, accessed 31 October 2017.

Blom R. (1991) Diverging Patterns of Change: Finland and Soviet Union. Department of Sociology and Social Psychology. Working Papers no B31, Tampere: University of Tampere.

Blom R., Melin H., Sarno A., Sarno I. (2007) Managers and Management in Russia, Saint Petersburg: St Petersburg State University of Economics and Finance Publishing House.

Borodkin L.I. (2010) Neformal'nye praktiki rabochikh sovetskoj promyshlennosti v usloviyakh postsovetskoj transformatsii [Informal Practices of Workers in Soviet Industries in the Conditions of post-Soviet Transformation]. "Sovetskoe nasledstvo». Otrazhenie proshlogo $v$ sotsial'nykh $i$ ekonomicheskikh praktikakh sovremennoj Rossii ["Soviet Heritage". The Reflection of the Past in Social and Economic Practices of Contemporary Russia] (eds. Borodkin L.I., Kessler Kh., Sokolov A.K.), Moscow: ROSSPEN, pp. 224-252.

Brewster C., Larsen H.H. (2000) The Northern European Dimension. Human Resource Management in Northern Europe: Trends, Dilemmas and Strategy (eds. Brewster C., Larsen H.H.), Oxford: Blackwell Publishers Ltd, pp. 24-38.

Burawoy M. (1981) Terrains of Contest: Factory and State under Capitalism and Socialism. Socialist Review, vol. 11, no 4, pp. 83-124.

Burawoy M., Krotov P. (1993) The Soviet Transition from Socialism to Capitalism. Worker Control and Economic Bargaining in the Wood Industry. What about the Workers? Workers and the Transition to Capitalism in Russia (eds. Clarke S., Fairbrother P., Burawoy M., Krotov P.), London: Verso, pp. 56-90.

Castells M., Himanen P. (2002) The Information Society and the Welfare State. The Finnish Model, Oxford: Oxford University Press.

Clarke S. (1993) The Contradictions of 'State Socialism'. What about the Workers? Workers and the Transition to Capitalism in Russia (eds. Clarke S., Fairbrother P., Burawoy M., Krotov P.), London: Verso, pp. 5-29.

Clarke S. (2004) A Very Soviet Form of Capitalism? The Management of Holding Companies in Russia. Post-Communist Economies, vol. 16, no 4, pp. 405-422.

Clarke S. (2006) The Development of Capitalism in Russia, London: Routledge.

Clarke S., Borisov V. (1999) New Forms of Labour Contract and Labour Flexibility in Russia. Economics of Transition, vol. 7, no 3, pp. 593-614.

Fey C.F. (2005) Opening the Black Box of Motivation: A Cross-cultural Comparison of Sweden and Russia. International Business Review, vol. 14, no 3, pp. 345-367. 
Fey C.F., Björkman I. (2007) The Effect of Human Resource Management Practices on MNC Subsidiary Performance in Russia. Human Resource Management in Russia (eds. Domsch M.E., Lidokhover T.), Aldershot: Ashgate, pp. 307-330.

Fey C.F., Shekshnia S. (2011) The Key Commandments for Doing Business in Russia. Organizational Dynamics, vol. 40, no 1, pp. 57-66.

Gilliland S.W. (1993) The Perceived Fairness of Selection Systems: An Organizational Justice Perspective. The Academy of Management Review, vol. 18, no 4, pp. 694-734.

Gimpelson V., Kapeliushnikov R. (2011) Labor Market Adjustment: Is Russia Different? IZA Discussion Paper No. 5588. Available at: http://ftp.iza.org/dp5588.pdf, accessed 31 October 2017.

Green F. (2006) Demanding Work. The Paradox of Job Quality in the Affluent Economy, New Jersey, USA: Princeton University Press.

Gurkov I., Zelenova O. (2009) Managing Human Resources in Russia. Managing Human Resources in Central and Eastern Europe (eds. Morley M.J., Heraty N., Michailova S.), London: Routledge, pp. 278-312.

Gurkov I., Zelenova O., Saidov Z. (2012) Mutation of HRM Practices in Russia: an Application of CRANET Methodology. International Journal of Human Resource Management, vol. 23, no 7, pp. 1289-1302.

Hartikainen A., Anttila T., Oinas T., Nätti J. (2010) Is Finland Different? Quality of Work Among Finnish and European Employees. Research on Finnish Society, no 3, pp. 29-41.

Hollinshead G. (2007) Pay in Russia. Human Resource Management in Russia (eds. Domsch M.E., Lidokhover T.), Aldershot: Ashgate, pp. 227-242.

Javidan M., Dorfman P.W., de Luque M.S., House R.J. (2006) In the Eye of the Beholder: Cross Cultural Lessons in Leadership from Project GLOBE. Academy of Management Perspectives, vol. 20, no 1, pp. 67-90.

Kapelyushnikov R., Kuznetsov A., Kuznetsova O. (2011) Diversity with Capitalism: the Russian Labour Market Model. Employee Relations, vol. 33, no 4, pp. 395-412.

Ledeneva A. (2008) Blat and Guanxi: Informal Practices in Russia and China. Comparative Studies in Society and History, vol. 50, no 1, pp. 118-144.

Lehto A.-M., Sutela H. (2008) Työolojen kolme vuosikymmentä. Työolotutkimusten tuloksia 1977-2008 [The Results of the Studies of Labor Conditions. Three Decades], Helsinki: Tilastokeskus.

Lindell M., Arvonen J. (1996) The Nordic Management Style in a European Context. International Studies on Management \& Organization, vol. 26, no 3, pp. 73-91.

Liuhto K. (1999) The Transformation of the Soviet Enterprise and Its Management: A Literature Review. ESRC Centre for Business Research. University of Cambridge Working Paper, no 146 , pp. 1-26.

Magun V., Rudnev M. (2012) Basic Values of Russians and Other Europeans (According to the Materials of Surveys in 2008). Problems of Economic Transition, vol. 54, no 10, pp. 31-64.

Melin H. (2002) Change and Continuity in Russian Work Organization. Restoration of Class Society in Russia? (ed. Nikula J.), Hampshire: Ashgate, pp. 60-75.

Melin H. (ed.) (2005) Social Structure, Public Space and Civil Society in Karelia, Helsinki: Kikimora Publications.

Moen E., Lilja K. (2005) Change in Coordinated Market Economies: The Case of Nokia and Finland. Changing Capitalisms? Internationalization, Institutional Change, and Systems of Economic Organization (eds. Morgan G., Whitley R., Moen E.), Oxford: Oxford University Press, pp. 352-379.

Nikula J. (1997) From State-Dependency to Genuine Worker Movement? The Working Class in Socialism and Post-Socialism. Academic dissertation. Faculty of Social Sciences, University of Tampere.

Palosuo H. (2000) How Good is "Normal” Health? An Exercise in Russian-Finnish Comparative Survey Methodology. Idäntutkimus, vol. 7, no 3-4, pp. 41-70.

Parent-Thirion A., Fernández Macías E., Hurley J., Vermeylen G. (2007) Fourth European Working Conditions Survey. European Foundation for the Improvement of Living and Working Conditions, Luxembourg: Office for Official Publications of the European Communities. 
Available at: https://www.eurofound.europa.eu/publications/report/2007/working-conditions/fourth-european-working-conditions-survey, accessed 31 October 2017.

Perceptions of Living Conditions in an Enlarged Europe (2004). European Commission. Directorate-General for Employment and Social Affairs, Luxembourg: Office for Official Publications of the European Communities. Available at: https://www.eurofound.europa.eu/sites/ default/files/ef_files/pubdocs/2003/113/en/1/ef03113en.pdf, accessed 31 October 2017.

Popova I. (2010) Autonomy at Work as Feature of Flexible Employment. Social Class in the Russian Society (eds. Nikula J., Chernysh M.), Saarbrucken: Lambert Academic Publishing, pp. 80-103.

Puffer S.M., McCarthy D.J. (2011) Two Decades of Russian Business and Management Research: An Institutional Theory Perspective. Academy of Management Perspectives, vol. 25, no 2, pp. 21-36.

Rogaczewska A.P., Larsen H.H., Nordhaug O., Døving E., Gjelsvik M. (2004) Denmark and Norway: Siblings or Cousins? Human Resource Management in Europe: Evidence of Convergence? (eds. Brewster C., Mayrhofer W., Morley M.), Oxford: Elsevier Butterworth-Heinemann, pp. 231-278.

Rose R. (2008) Is Russia Becoming a Normal Society? Demokratizatsiya, vol. 16, no 1, pp. 75-86.

Saari T., Melin H., Balabanova E., Efendiev A. (2017) Job Demands and Resources as Antecedents of Work Engagement: Comparative Research on Finland and Russia. Baltic Journal of Management, vol. 12, no 2, pp. 240-254.

Sarno I. (2012) Learning Managers in a Transforming Economy. The Case of Russia 1999-2006. Acta Universitatis Tamperensis 1709, Tampere: Tampere University Press.

Smirnykh L., Wörgötter A. (2013) Why Do Russian Firms Use Fixed-Term and Agency Work Contracts? IZA Policy Paper, no 54. Available at: http://ftp.iza.org/pp54.pdf, accessed 31 October 2017.

Stokke T.A., Thörnqvist Ch. (2001) Strikes and Collective Bargaining in the Nordic Countries. European Journal of Industrial Relations, vol. 7, no 3, pp. 245-257.

Sutela H., Lehto A.-M. (2014) Työolojen muutokset 1977-2013 [Changes in the Labor Conditions 1977-2013], Helsinki: Tilastokeskus.

Swerdlow S., Roehl W.S. (2003) Managing Job Satisfaction in the Russian Lodging Industry: Cultural Analysis and Implications. Managing Employee Attitudes and Behaviors in the Tourism and Hospitality Industry (ed. Kusluvan S.), New York: Nova Science Publishers, pp. 357-374.

Tolvanen T. (2012) Eräs Venäjä-tutkimuksen myytti [A Myth on the Russian Sociological Studies]. Idäntutkimus, vol. 19, no 3, pp. 84-88.

Tomanovic S., Ignjatovic S. (2006) The Transition of Young People in a Transitional Society: the Case of Serbia. Journal of Youth Studies, vol. 9, no 3, pp. 269-285.

Walker C. (2010) Learning to Labour in Post-Soviet Russia: Vocational Youth in Transition, Oxford: Routledge.

Yakubovich V., Kozina I. (2007) Recruitment at Russian Enterprises. Human Resource Management in Russia (eds. Domsch M.E., Lidokhover T.), Aldershot: Ashgate, pp. 153-169.

Ylöstalo P. (2007) Keskustelua suomalaisen työelämän luonteesta ja sen muuttumisesta [The Discussion of Labor Life and Its Changes in Finland]. Eläketurvakeskuksen keskustelualoitteita, no 4, Helsinki: Eläketurvakeskus. 


\title{
Труд в Финляндии и России: сравнительное исследование
}

\author{
Т. СААРИ*, М. СИППОЛА**, Х. МЕЛИН***, А. ЭФЕНДИЕВ****, \\ Е. БАЛАБАНОВА*****
}

\begin{abstract}
*Тиина Саари - научный сотрудник, Университет Тампере, Финляндия. Адрес: 4 Kalevantie, 33100, Tampere, Finland. E-mail: tiina.p.saari@uta.fi

**Маркку Сиппола - преподаватель, Университет Тампере, Финляндия. Адрес: 4 Kalevantie, 33100, Tampere, Finland. E-mail: Markku.Sippola@uta.fi

***Харри Мелин - профессор социологии, проректор, Университет Тампере, Финляндия. Адрес: 4 Kalevantie, 33100, Tampere, Finland. E-mail: harri.melin@uta.fi

****Азер Эфендиев - доктор философских наук, профессор, Национальный исследовательский университет «Высшая школа экономики». Адрес: 110100, Москва, ул. Мясницкая, д. 20. E-mail: efendiev@hse.ru

*****Евгения Балабанова - доктор социологических наук, профессор, Национальный исследовательский университет «Высшая школа экономики». Адрес: 110100, Москва, ул. Мясницкая, д. 20. E-mail: balabanova@hse.ru
\end{abstract}

Цитирование: Saari T., Sippola M., Melin Н., Efendiev A., Balabanova E. (2018) Comparing Finnish and Russian Work Life. Mir Rossii, vol. 27, no 2, pp. 90-108. DOI: $10.17323 / 1811-038 X-2018-27-2-90-108$

В статье сравниваются трудовые отношения и условия труда в Финляндии и России по нескольким ключевым показателем.

Во-первых, определяется отношение к оплате труда, ее роли как мотиватора трудовой деятельности. В России в отношении к труду традиционно преобладали инструментальные ценности. Этому в немалой степени способствовало установление жесткого временного регламента присутствия на рабочем месте и процедуры увольнения. В отличие от скандинавских стран работники в постсоветской России считают занятость важным жизненным приоритетом. Это связано с тем, что формальный аспект социальной политики в России представлен гораздо слабее, чем в странах Скандинавии. Одним из примеров этого может служить система поддержки безработных, и поскольку в России она малоэффективна, работники придают занятости большое значение.

Второй важный показатель, демонстрирующий различия между Финляндией и Россией, - это наличие дискриминации и фаворитизм, имеющий источником неформальные отношения. В Финляндии показатель фаворитизма в сфере труда всегда был гораздо ниже, чем в России. Третий показатель характеризует разные практики управления в России и Финляндии. В Финляндии руководители гораздо более терпимо относятся к возможным трудовым конфликтам. У финских руководителией широко практикуется ведение переговоров с влиятельными профсоюзами. В России традиционно доминирует авторитарный тип руководства, уходящий корнями еще в советскую эпоху. Данные исследования показывают, что имеющиеся различия остаются, несмотря на тенденцию их смягчения. Например, работники в Финляндии и России отмечают примерно схожий уровень удовлетворенности качеством руководства. Однако при ближайшем рассмотрении, при фокусировке исследования на отдельных показателях удовлетворенности выясняется, что российские 
респонденты гораздо ниже оценивают своих руководителей, чем респонденты в Финляндии. Наибольшие различия обнаруживаются в измерении доверия: россияне гораздо меньше доверяют руководству предприятия, чем финны.

Исследование продемонстрировало не только различия в сфере труда в Финляндии и России, но и нарастающее сходство по некоторым показателям. Переход к рынку существенно изменил условия труда в России и создал предпосылки для сближения России и Финляндии по ряду параметров. Например, в России доля тех, кто фиксирует случаи дискриминации и фаворитизма, уменьшается, в то время как в Финляндии она остается прежней. Вместе с тем в некоторых аспектах сближения не происходит. Например, стили руководства в России по-прежнему тяготеют к авторитаризму, в то время как в Финляндии сохраняются практики диалоговых отношений между руководством и работниками. Различия подобного рода имеют источником разные культуры и традиции. Культурный фактор консервирует некоторые из практик прошлого, затрудняя изменения, которые стимулируются рыночным типом отношений.

В целом есть основания говорить о том, что труд в России организован примерно так же, как в большинстве европейских стран. По многим показателям Россия близка к Финляндии, причем не только в государственном, но и частном секторе экономики. Отмеченные изменения подсказывают необходимость дальнейших исследований в этом направлении.

Ключевые слова: трудовые отношения, заработная плата, качество трудовой жизни, дискриминация на рабочем месте, стили руководства

\section{Литература}

Алашев С.Ю., Тарковская И.Н., Лапшова Е.М. (1997) Подшипниковый завод «Кольцо»: консерватизм формальных и неформальных структур // Кабалина В.И. (ред.) Предприятия и рынок: динамика управления и трудовых отношений в переходный период (опыт монографических исследований 1989-1995 гг.). М.: РОССПЕН. С. 114-144.

Бородкин Л.И. (2010) Неформальные практики рабочих советской промышленности в условиях постсоветской трансформации // Бородкин Л.И., Кесслер Х., Соколов А.К. (ред.) «Советское наследство». Отражение прошлого в социальных и экономических практиках современной России. М.: РОССПЕН. С. 224-252.

Alasoini T., Antila J., Hakonen N., Hasu M., Lyly-Yrjänäinen M., Niemi M., Pakarinen T., Ramstad E., Stålhammar H. (2016) Hyvä työelämä Suomen kilpailukykytekijänä: työelämäbrändityöryhmän raportti. Työja elinkeinoministeriön julkaisuja 42/2016, Helsinki: Työja elinkeinoministeriö.

Balabanova E., Efendiev A., Ehrnrooth M., Koveshnikov A. (2015) Idiosyncrasy, Heterogeneity and Evolution of Managerial Styles in Contemporary Russia // Baltic Journal of Management, vol. 10, no 1, pp. 2-29.

Balykina G. (2015) Power Distance and Modern Russian Business. Presentation at "Kitekintések 25 éves a győri közgazdászképzés”, Kautz Gyula Emlékkonferencia, on 11 June 2015 // http://kgk.sze.hu/images/dokumentumok/kautzkiadvany2015/Balykina.pdf

Blom R. (1991) Diverging Patterns of Change: Finland and Soviet Union. Department of Sociology and Social Psychology. Working Papers no B31, Tampere: University of Tampere.

Blom R., Melin H., Sarno A., Sarno I. (2007) Managers and Management in Russia, Saint Petersburg: St. Petersburg State University of Economics and Finance Publishing House. 
Brewster C., Larsen H.H. (2000) The Northern European Dimension // Human Resource Management in Northern Europe: Trends, Dilemmas and Strategy (eds. Brewster C., Larsen H.H.), Oxford: Blackwell Publishers Ltd, pp. 24-38.

Burawoy M. (1981) Terrains of Contest: Factory and State under Capitalism and Socialism // Socialist Review, vol. 11, no 4, pp. 83-124.

Burawoy M., Krotov P. (1993) The Soviet Transition from Socialism to Capitalism. Worker Control and Economic Bargaining in the Wood Industry // What about the Workers? Workers and the Transition to Capitalism in Russia (eds. Clarke S., Fairbrother P., Burawoy M., Krotov P.), London: Verso, pp. 56-90.

Castells M., Himanen P. (2002) The Information Society and the Welfare State. The Finnish Model, Oxford: Oxford University Press.

Clarke S. (1993) The Contradictions of 'State Socialism' // What about the Workers? Workers and the Transition to Capitalism in Russia (eds. Clarke S., Fairbrother P., Burawoy M., Krotov P.), London: Verso, pp. 5-29.

Clarke S. (2004) A Very Soviet Form of Capitalism? The Management of Holding Companies in Russia // Post-Communist Economies, vol. 16, no 4, pp. 405-422.

Clarke S. (2006) The Development of Capitalism in Russia, London: Routledge.

Clarke S., Borisov V. (1999) New Forms of Labour Contract and Labour Flexibility in Russia // Economics of Transition, vol. 7, no 3, pp. 593-614.

Fey C.F. (2005) Opening the Black Box of Motivation: A Cross-cultural Comparison of Sweden and Russia // International Business Review, vol. 14, no 3, pp. 345-367.

Fey C.F., Björkman I. (2007) The Effect of Human Resource Management Practices on MNC Subsidiary Performance in Russia // Human Resource Management in Russia (eds. Domsch M.E., Lidokhover T.), Aldershot: Ashgate, pp. 307-330.

Fey C.F., Shekshnia S. (2011) The Key Commandments for Doing Business in Russia // Organizational Dynamics, vol. 40, no 1, pp. 57-66.

Gilliland S.W. (1993) The Perceived Fairness of Selection Systems: An Organizational Justice Perspective // The Academy of Management Review, vol. 18, no 4, pp. 694-734.

Gimpelson V., Kapeliushnikov R. (2011) Labor Market Adjustment: Is Russia Different? // IZA Discussion Paper No. 5588 // http://ftp.iza.org/dp5588.pdf

Green F. (2006) Demanding Work. The Paradox of Job Quality in the Affluent Economy, New Jersey, USA: Princeton University Press.

Gurkov I., Zelenova O. (2009) Managing Human Resources in Russia // Managing Human Resources in Central and Eastern Europe (eds. Morley M.J., Heraty N., Michailova S.), London: Routledge, pp. 278-312.

Gurkov I., Zelenova O., Saidov Z. (2012) Mutation of HRM Practices in Russia: an Application of CRANET Methodology // International Journal of Human Resource Management, vol. 23, no 7, pp. 1289-1302.

Hartikainen A., Anttila T., Oinas T., Nätti J. (2010) Is Finland Different? Quality of Work Among Finnish and European Employees // Research on Finnish Society, no 3, pp. 29-41.

Hollinshead G. (2007) Pay in Russia // Human Resource Management in Russia (eds. Domsch M.E., Lidokhover T.), Aldershot: Ashgate, pp. 227-242.

Javidan M., Dorfman P.W., de Luque M.S., House R.J. (2006) In the Eye of the Beholder: Cross Cultural Lessons in Leadership from Project GLOBE // Academy of Management Perspectives, vol. 20, no 1, pp. 67-90.

Kapelyushnikov R., Kuznetsov A., Kuznetsova O. (2011) Diversity with Capitalism: the Russian Labour Market Model // Employee Relations, vol. 33, no 4, pp. 395-412.

Ledeneva A. (2008) Blat and Guanxi: Informal Practices in Russia and China // Comparative Studies in Society and History, vol. 50, no 1, pp. 118-144.

Lehto A.-M., Sutela H. (2008) Työolojen kolme vuosikymmentä. Työolotutkimusten tuloksia 1977-2008, Helsinki: Tilastokeskus.

Lindell M., Arvonen J. (1996) The Nordic Management Style in a European Context // International Studies on Management \& Organization, vol. 26, no 3, pp. 73-91.

Liuhto K. (1999) The Transformation of the Soviet Enterprise and Its Management: A Literature Review // ESRC Centre for Business Research. University of Cambridge Working Paper, no 146 , pp. 1-26. 
Magun V., Rudnev M. (2012) Basic Values of Russians and Other Europeans (According to the Materials of Surveys in 2008) // Problems of Economic Transition, vol. 54, no 10, pp. 31-64.

Melin H. (2002) Change and Continuity in Russian Work Organization // Restoration of Class Society in Russia? (ed. Nikula J.), Hampshire: Ashgate, pp. 60-75.

Melin H. (ed.) (2005) Social Structure, Public Space and Civil Society in Karelia, Helsinki: Kikimora Publications.

Moen E., Lilja K. (2005) Change in Coordinated Market Economies: The Case of Nokia and Finland. Changing Capitalisms? // Internationalization, Institutional Change, and Systems of Economic Organization (eds. Morgan G., Whitley R., Moen E.), Oxford: Oxford University Press, pp. 352-379.

Nikula J. (1997) From State-Dependency to Genuine Worker Movement? The Working Class in Socialism and Post-Socialism. Academic dissertation. Faculty of Social Sciences, University of Tampere.

Palosuo H. (2000) How Good is "Normal" Health? An Exercise in Russian-Finnish Comparative Survey Methodology // Idäntutkimus, vol. 7, no 3-4, pp. 41-70.

Parent-Thirion A., Fernández Macías E., Hurley J., Vermeylen G. (2007) Fourth European Working Conditions Survey // European Foundation for the Improvement of Living and Working Conditions, Luxembourg: Office for Official Publications of the European Communities // https:/www.eurofound.europa.eu/publications/report/2007/working-conditions/ fourth-european-working-conditions-survey

Perceptions of Living Conditions in an Enlarged Europe (2004) // European Commission. Directorate-General for Employment and Social Affairs, Luxembourg: Office for Official Publications of the European Communities // https://www.eurofound.europa.eu/sites/default/ files/ef files/pubdocs/2003/113/en/1/ef03113en.pdf

Popova I. (2010) Autonomy at Work as Feature of Flexible Employment // Social Class in the Russian Society (eds. Nikula J., Chernysh M.), Saarbrucken: Lambert Academic Publishing, pp. 80-103.

Puffer S.M., McCarthy D.J. (2011) Two Decades of Russian Business and Management Research: An Institutional Theory Perspective // Academy of Management Perspectives, vol. 25, no 2, pp. 21-36.

Rogaczewska A.P., Larsen H.H., Nordhaug O., Døving E., Gjelsvik M. (2004) Denmark and Norway: Siblings or Cousins? // Human Resource Management in Europe: Evidence of Convergence? (eds. Brewster C., Mayrhofer W., Morley M.), Oxford: Elsevier Butterworth-Heinemann, pp. 231-278.

Rose R. (2008) Is Russia Becoming a Normal Society? // Demokratizatsiya, vol. 16, no 1, pp. 75-86.

Saari T., Melin H., Balabanova E., Efendiev A. (2017) Job Demands and Resources as Antecedents of Work Engagement: Comparative Research on Finland and Russia // Baltic Journal of Management, vol. 12, no 2, pp. 240-254.

Sarno I. (2012) Learning Managers in a Transforming Economy. The Case of Russia 1999-2006. Acta Universitatis Tamperensis 1709, Tampere: Tampere University Press.

Smirnykh L., Wörgötter A. (2013) Why Do Russian Firms Use Fixed-Term and Agency Work Contracts? // IZA Policy Paper, no 54 // http://ftp.iza.org/pp54.pdf

Stokke T.A., Thörnqvist Ch. (2001) Strikes and Collective Bargaining in the Nordic Countries // European Journal of Industrial Relations, vol. 7, no 3, pp. 245-257.

Sutela H., Lehto A.-M. (2014) Työolojen muutokset 1977-2013, Helsinki: Tilastokeskus.

Swerdlow S., Roehl W.S. (2003) Managing Job Satisfaction in the Russian Lodging Industry: Cultural Analysis and Implications // Managing Employee Attitudes and Behaviors in the Tourism and Hospitality Industry (ed. Kusluvan S.), New York: Nova Science Publishers, pp. 357-374.

Tolvanen T. (2012) Eräs Venäjä-tutkimuksen myytti // Idäntutkimus, vol. 19, no 3, pp. 84-88.

Tomanovic S., Ignjatovic S. (2006) The Transition of Young People in a Transitional Society: the Case of Serbia // Journal of Youth Studies, vol. 9, no 3, pp. 269-285.

Walker C. (2010) Learning to Labour in Post-Soviet Russia: Vocational Youth in Transition, Oxford: Routledge.

Yakubovich V., Kozina I. (2007) Recruitment at Russian Enterprises // Human Resource Management in Russia (eds. Domsch M.E., Lidokhover T.), Aldershot: Ashgate, pp. 153-169.

Ylöstalo P. (2007) Keskustelua suomalaisen työelämän luonteesta ja sen muuttumisesta // Eläketurvakeskuksen keskustelualoitteita, no 4, Helsinki: Eläketurvakeskus. 